[Highlight]

\title{
二维平面异质结构实现光生载流子快速分离和传输
}

\author{
吴 凯 \\ (北京大学化学与分子工程学院, 北京 100871)
}

\section{Two-Dimensional in-Plane Heterostructure Achieving Fast Photocarrier Separation and Transfer}

\author{
WU Kai \\ (School of Chemistry and Molecular Engineering, Peking University, Beijing 100871, P. R. China)
}

随着全球经济和技术的快速发展, 传统的化 石能源的过度消耗引起了严重的环境污染和能源 短缺等世界性问题, 开发新型能源技术已成为当 前人类发展所面临的重要目标 ${ }^{1}$ 。利用光催化水分 解把太阳能转变为氢能的方式被普遍认为是解决 人类未来能源的有效途径之一, 这亟需高效、稳 定和廉价的太阳能水分解制氢催化剂材料。然 而, 在体相材料的光催化水分解过程中, 长的迁 移距离、缓慢的迁移速率使得大量光生电子-空穴 在到达表面活性位点前就发生复合, 严重制约了 光解水能量转换效率的提升。

为实现光生载流子的快速分离, 需要发展新 材料或构建新结构。传统的掺杂改性能够加快光 生载流子传输, 同时也极易引入光生载流子复合 中心; 由二维材料有序堆叠形成的范德瓦尔斯异 质结构能够有效减少光生载流子的体相复合, 但 其弱的层间范德瓦尔斯力难以驱动光生载流子在 层间的有效传输 ${ }^{2-5}$ 。为克服光生载流子迁移驱动 力不足的缺陷, 需要在二维材料内引入较强的内 建电场并进一步改善其电荷的传导特性, 才能够 引导光生载流子在二维平面内的快速传输, 实现 光生载流子的有效分离, 显著提升其光催化水分 解效率。

最近, 中国科学技术大学国家同步辐射实验 室韦世强教授研究组以二维氮化碳 $\left(\mathrm{g}-\mathrm{C}_{3} \mathrm{~N}_{4}\right)$ 材料为 基质, 提出了构建新型二维 $\pi$ 共轭平面异质结构实 现光生载流子在二维平面内快速分离的理念, 并 利用同步辐射技术深入研究异质结构的构效关 系, 研究结果发表在 Journal of the American
Chemical Society 杂志上 ${ }^{6}$ 。通过将碳环嵌入类石墨 烯材料 $s p^{2}$ 杂化的二维平面内形成 $\pi$ 共轭键连接的 平面异质结构, 利用局域微区异质界面内建电场 及时快速地驱动光生电子和空穴空间分离, 显著 提升了光生载流子的平均迁移长度和有效寿命。 同步辐射 $\mathrm{X}$ 射线吸收谱学技术以及电化学方法揭 示了光生电子-空穴快速分离的内在机制, 发现碳 环强的电子亲和力能及时俘获光生电子, 并将平 面电荷去局域化促进空穴传输, 从而有效抑制光 生载流子的复合。他们所设计的 $\mathrm{C}_{\mathrm{ring}}-\mathrm{C}_{3} \mathrm{~N}_{4}$ 平面异质 结构不但能有效拓展催化剂对太阳光谱的吸收, 而且显著提升了其可见光全解水的效率。该工作 有效分离了光生载流子, 极大提高了太阳能转换 效率, 为构建新型太阳能转换材料提供了新的理 念和结构设计。

\section{References}

(1) Lewis, N. S. Science 2016, 351, 353. doi: 10.1126/science. aad5117

(2) Zhang, G.; Zhang, M.; Ye, X.; Qiu, X.; Lin, S.; Wang, X. $A d v$. Mater. 2014, 26, 805. doi: 10.1002/adma.201303611

(3) Deng, D.; Novoselov, K. S.; Fu, Q.; Zheng, N.; Tian, Z.; Bao, X. Nat. Nanotech. 2016, 11, 218. doi: 10. 1038/nnano.2015.340

(4) Duan, X.; Wang, C.; Pan, A.; Yu, R.; Duan, X. Chem. Soc. Rev. 2015, 44, 8859. doi: 10.1039/C5CS00507H

(5) Di Valentin, C.; Pacchioni, G. Acc. Chem. Res. 2014, 47, 3233. doi: 10.1021/ar4002944

(6) Che, W.; Cheng, W. R.; Yao, T.; Tang, F. M.; Liu, W.; Su, H.; Huang, Y. Y.; Liu, Q. H.; Liu, J. K.; Hu, F. C.; Pan, Z. Y.; Sun, Z. H.; Wei, S. Q. J. Am. Chem. Soc. 2017, doi: 10.1021/jacs.6b11878 